\title{
Design of a Board Game With Augmented Reality
}

This paper presents the design process of a board game with augmented reality. The board games have remained attractive in this time of complete digitalization. The experience of hands on play has been the key feature of the board game. By introducing AR in the board games this key feature is kept together with digitalization of some elements of the gameplay. Augmented reality games provide players with a rich and potentially unlimited range of interaction possibilities. Implementation of AR creates added value to the game. We want to enhance the game experience by combining the best features from classical board games and video games. The benefits of playing board games are numerous contrary to the video games. By implementing AR, the game will draw interest of the video games players too.

This paper presents an example of the design of what is known as AR Board Game, a class of table-top games that combines handheld devices (such as smart phones) with physical game pieces to create a merged physical/virtual game on the table-top. Along with that, the paper describes the process of designing a board game that incorporates AR, along with technical implementation. The design process is performed using the well-known principles (fig.1).

The goal of the research is to identify the benefits for the players of introducing digital technology in the analogue world of the board games. Comparison of the user experience in the case of using just the board game and the board game with $A R$ is conducted. For the sample under consideration were accounted board game players but also video games players. Results of the conducted comparison are presented and discussed. At the end the whole experience of designing such a product is presented along with ideas for further work.

Keywords: augmented reality; board game; design process; gameplay.

\section{INTRODUCTION}

Board games have existed from 3500 BC in Ancient Egypt. They have a certain amount of devoted players but that number has significantly decreased since the emergence of the video games. They are both very different but the idea to entertain and amuse the crowd is same. Nevertheles, it is evident that the number of video games players is increasing in account to board game players.

With the research presented in this paper we are trying to increase the interest for board games, because we believe that board games have huge social impact on young individuals. Our proposal is to implement augmented reality in the game play creating AR board game. In our opinion, AR board game will implement new levels of intrigue and excitement but still maintain the social factor that video games lack.

Comparing board games and video games [1], statistic results indicated that satisfaction degree of

Received: June 2018, Accepted: December 2018. Correspondence to: Tashko Rizov, Assistant Professor, University of "Ss. Cyril and Methodius" in Skopje, Faculty of Mechanical Engineering, N. Macedonia E-mail: tashko.rizov@mf.edu.mk doi:10.5937/fmet1902253R

(C) Faculty of Mechanical Engineering, Belgrade. All rights reserved digital computer games declined in visceral, behavioural and reflective levels when compared with traditional board games (Fig. 1). The appearance of the traditional board game could impress people at first sight and reduce errors in operation. Players can feel intimacy, vivid imagery, sympathetic responses and satisfaction while playing the board game.

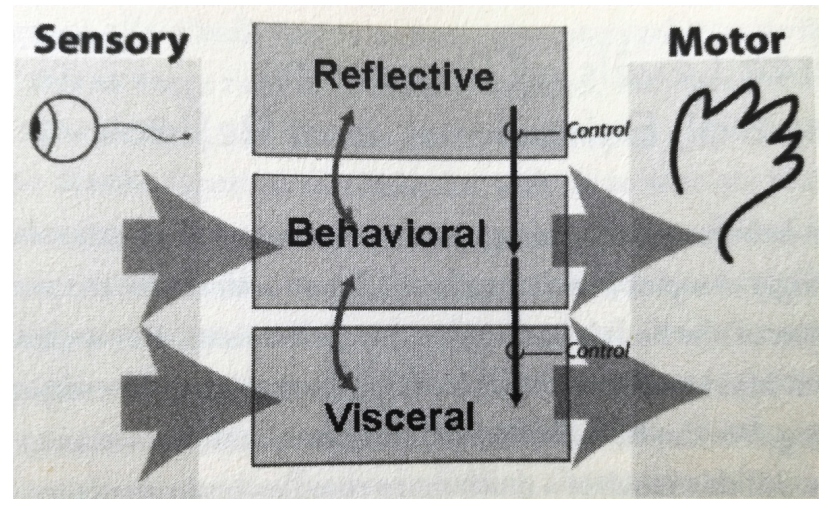

Figure 1. Levels of processing: Visceral, Behavioural and Reflective (Norman 2004).

The results also concluded that traditional games not only evoked users' stronger emotional reactions, both positive and negative, but also received higher prefe- 
rences. Regarding social interaction, traditional games could improve interpersonal relationships. New digital games could not replace the sense of social interaction created by traditional physical games. Research conducted by Lazzaro [2] is confirming previously said that playing in a group emotes more frequently and with more intensity than those playing on their own. Group play adds new behaviours, rituals, and emotions that make games more exciting.

\section{BACKGROUND}

The development of the AR technology and affordances of the AR devices have enabled implementation of AR in different applications. In board games AR has been in use for some time and has been used for different purposes. Magerkurth and colleagues [6,7] developed AR KnightMage, board-based role-playing adventure game. Physical game elements, such as dice and avatars, affect the virtual game world when moved and placed on top of the projected display [4]. They use stationary camera placed on top of the board and use radio identification for board sensing. Lee and colleagues [8] developed a table-top card battle game using front projection. Optically tracked markers are attached below the cards, and the cards are visible to a camera underneath a transparent glass table. Molla and Lepetit [9] are implementing shape recognition of the pawns for Monopoly using web cam. The element that they incorporate in the game is $3 \mathrm{D}$ imaginary of the chance field and of the pawns [5]. Their implementation does not include game logic. Cooper et al. [10] propose an AR system for Chinese checkers using markers. They explore user interface issues for table top projected AR entertainment applications. Ngyuyen and colleagues [12] implemented a collaborative handheld augmented reality with Art of Defence, board game. The authors define an AR board game as "a class of tabletop games which combine handheld computers such as camera phones with physical game pieces to create a merged physical/virtual game on the tabletop." Their goal is to explore the affordances and constraints of HandheldAugmented Reality (HAR) interfaces for collaborative social games. From the conducted user study showed high levels of enjoyment among player and experience unlike non-AR computer games [13]. This is something that we have been also working on in our research.

As computers increased in power during the past few years, researchers have ported AR infrastructures to hand-held devices that are less costly, simpler, and lighter than earlier wearable AR systems. Wagner and colleagues [11] demonstrated an AR train game using a camera equipped PDA device. A miniature physical railroad track on a flat surface is surrounded by fiducial markers for tracking [14]. Multiple players can each interact through a PDA [15]. Game play involves switching the track direction at intersections to avoid collisions among several trains. Mobile-phone-based AR games are also being actively investigated as an affordable AR system with multiplayer capabilities [16]. AR has potential in the board gaming industry, in creating mixed reality games, or AR games, as noted in [17]. The authors construct an AR setup with multiple users with head mounted displays. Their implementation focuses more on the technical challenges faced at categorising public vs. private information in games like roulette and mahjong (Chineese tile-based game). Implementation of the social aspects of traditional board games computer games is also found in [18]. The authors design and implement a multi-player game 'Pirates!' on handheld computers, using radiofrequency identification tags (RFID) to sense player locations. The game is an attempt at using elements of the world as a game board. A similar concept is described in [19] implementation of the popular video game Quake using AR. The first-person shooter ARQuake allows the player to roam around in the outside world while playing a game in the computer generated world. The game monsters res-ponded to the lighting conditions in the physical world to make them more visible. The implementation is very interesting, as it uses 'the world as a game board' in an innovative way. Oda and colleagues [20] are developing AR Racing car game. The physical interface is a board with markers which represent different object in the virtual environment.

Research of Andersan and colleagues [21] has different approach. They are combining the best features from classical board games and computer games in order to enhance the game play experience. They use traditional board game and convert it to a video game. They use ARToolkit platform to create the augmented part. The players have to have VR helmets with webcam or monitor in front of them.

Thakar [22] has different aim in his $\mathrm{PhD}$ thesis. He is using AR not for the amusement and enrichment of the gameplay but more introductions of new comers. He discovers that new comers don not bother reading the manuals and during the gameplay they bother other player. So, to solve this problem he is implementing the manual throughout the gameplay.

\section{ADDING AR IN A BOARD GAME}

The board game used in this scenario is called Small Star Empires and it is an abstract strategy game with grid movement mechanics (Fig. 2). The game is already designed and available on the market. At this point the development team has created two expansions of the game in order to enrich the game contents. In addition to the expansion of the game content the development team wanted to add augmented reality (AR) in order to further enrich the gaming experience.

The rules are pretty simple and straightforward. The ultimate goal of the game is to control more planets in the galaxy. With the Dawn of Discoveries expansion add a bit more depth and variety of play styles.

This expansion adds minerals, a technology deck and Research Stations. The minerals are placed in a cloth bag, shuffled, and 1 is randomly placed on each 1planet system. The technology deck is shuffled and a number are revealed depending on player count. Each player also receives 3 Research Stations in their colour. The Technology Cards are one-time-use powers you can buy during the game (Fig. 3). There will always be one card + the number of players' worth of cards available 
for purchase. They cost a combo of minerals and you cannot purchase multiples of the same techs. Once purchased, they go in front of you face up. When you use them, you flip them face down.

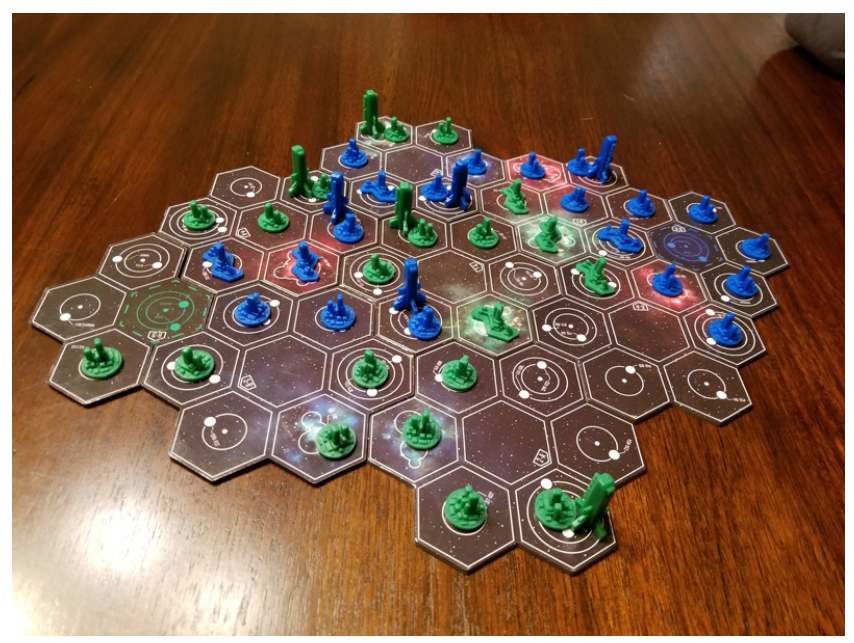

Figure 2. The game plan of the board game.

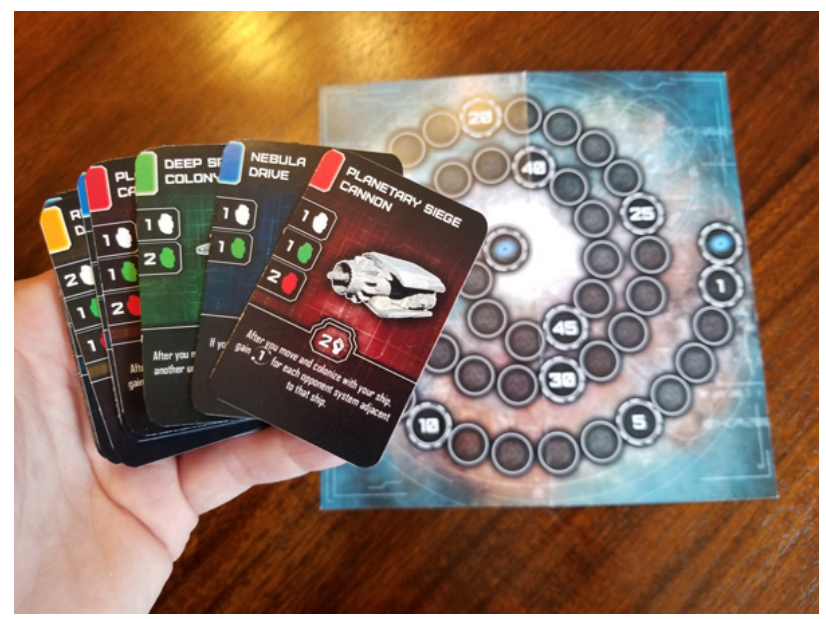

Figure 3. The technology cards.

During the design phase of the expansion and the opportunity to add AR features to the game a focus group was created. The goal of the focus group was to analyse the available opportunities in order to make an appropriate conclusion. The focus group is consisted of 25 members, 15 of which male and 10 female participants. Also, the focus group covers different education levels and areas. The group has experienced board game developers, experienced board game players, moderate game players and novice game players.

During this research an analysis was conducted with the focus group on the possible ways to introduce the augmentation to the game. The options were to use AR technology for desktop or laptop computers, for handheld devices or for Head-Mounted Displays (HMD). Considering the scenario of the game play and the setting of the game (a tabletop with players sitting around) the option for hand-held devices was selected as most suitable.

The next step was to choose for which elements of the game play the augmentation should be created. The options here are numerous. The main setback is the time needed to create 3D models of the graphic elements used in the game. Also, adding too much augmentation to the game would jeopardize the wanted hands-on experience which is the key element why players play board games over computer games. One of the analyzed options was to add augmentation to better explain the rules at the very beginning of the game. But this idea was overruled due to the fact that the focus of the research was to evaluate the effect of AR to the actual game play and not the supporting elements.

Considering the game plan, the most suitable solution for adding the augmentation were the Technology Cards. They are great to serve as markers and the elements shown as pictures on them are suitable to be presented in $3 \mathrm{D}$ using augmented reality. In this manner the player can get a better visualization of the element shown on the technology card and better understand its abilities.

Since the decision was locked on hand-held devices, as best solution for performing the augmentation was selected the software platform Augment. This software platform has a web based account manager and a free Android and iOS based app. Using the web based manager one can create a custom marker using a picture. The custom marker has to have a distinctive and unique pattern in order for the image recognition algorithm to be able to recognize it. Again, using the web based account manager one can add the 3D model and link the model and the marker. In that way, whenever a user of the app scans the custom marker, the app will display the appropriate 3D model in AR (Fig. 4).
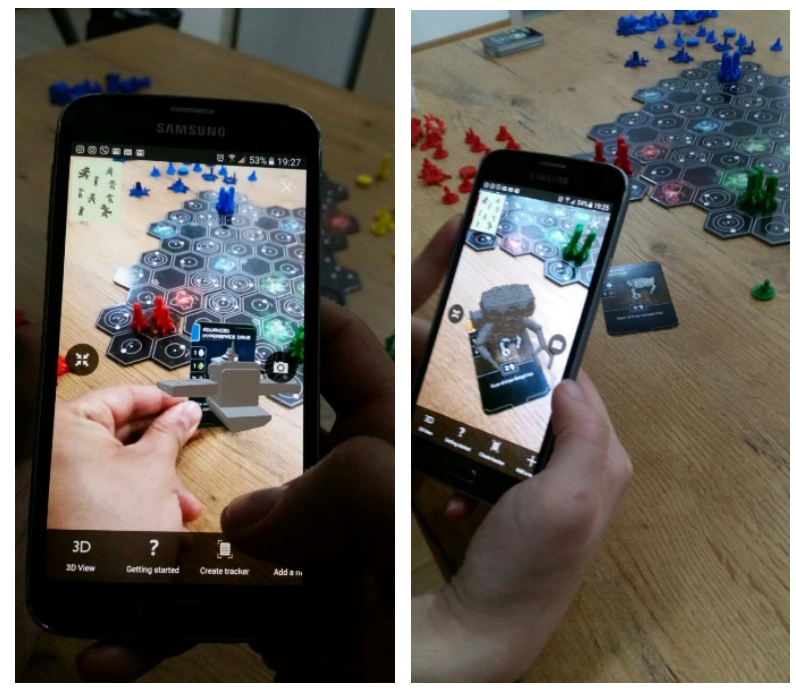

Figure 4. The technology cards presented in AR.

\section{RESULTS}

The first test of the results was with the focus group. The members of the group played the game with and without the AR feature. As discussed in the introduction, the developers of the game should enjoy playing themselves, otherwise others will not enjoy playing the game either. The focus group was the first test that helped us understand whether AR makes the game experience better. The result of the interview with the focus group showed that the feature adds an interesting experience to the game and it definitely attracts players to the game. 
The second test was at a board game tournament. This was a more focused experiment. The results of the conducted interview with the players after they played the game was that the AR experience is good to some extent. The effect of it would be much greater if the AR feature is used directly into the game play, meaning that using the AR feature you control elements of the game. Since this a board game that uses physical objects, this means that the AR feature should use object recognition instead of image recognition algorithms.

\section{CONCLUSION}

Implementation of AR in the board game made it more exciting attracting more players. Positive aspect of the $\mathrm{AR}$ is that is not invasive as video games. That means that one player can engage the AR elements if they want to and at the same time other players can play the board game itself without any additions. So depending on the preferences of the players the game can be adaptable.

By introducing AR in the board games this key feature is kept together with digitalization of some elements of the gameplay. Augmented reality games provide players with a rich and potentially unlimited range of interaction possibilities. Implementation of AR creates added value to the game. We want to enhance the game experience by combining the best features from classical board games and video games. The benefits of playing board games are numerous in contrary to the video games. By implementing AR, the game will draw interest of the video games players too.

\section{REFERENCES}

[1] Fang, Y.M., Chen, K.M. and Huang, Y.J., 2016. Emotional reactions of different interface formats: Comparing digital and traditional board games. Advances in Mechanical Engineering, 8 (3), p.1687814016641902.

[2] Lazzaro, N., 2004. Why we play games: Four keys to more emotion in player experiences. In Proceedings of GDC (Vol. 306).

[3] Norman, D.A., Emotional design, 2004.

[4] Pavlović A., i M. Živković. 2016. Roll Cage Design and Validation for a Rally Vehicle. FME Transactions 44, (4): 398-404.

[5] Ristevski S., R. Tashevski, i T. Rizov. 2017. Concept Design of a Sports Coupe with Ergonomic Analysis and Photorealistic Rendering. FME Transactions 45, (2): 288-293.

[6] Magerkurth, C. et al., 2004, May. Towards the next generation of tabletop gaming experiences. In Proceedings of Graphics interface 2004 (pp. 73-80). Canadian Human-Computer Communications Society.

[7] Magerkurth, C., Stenzel, R., Streitz, N. and Neuhold, E., 2003, October. A multimodal interaction framework for pervasive game applications. In Workshop at Artificial Intelligence in Mobile System (AIMS), Fraunhofer IPSI (pp. 1-8).

[8] Lee, W., Woo, W. and Lee, J., 2005, May. Tarboard: Tangible augmented reality system for table-top game environment. In 2nd International
Workshop on Pervasive Gaming Applications, PerGames (Vol. 5, No. 2.1).

[9] Molla, E. and Lepetit, V., 2010, October. Augmented reality for board games. In Mixed and Augmented Reality (ISMAR), 2010 9th IEEE International Symposium on (pp. 253-254). IEEE.

[10]Huynh, D.N.T., Raveendran, K., Xu, Y., Spreen, K. and MacIntyre, B., 2009, August. Art of defense: a collaborative handheld augmented reality board game. In Proceedings of the 2009 ACM SIGGRAPH symposium on video games (pp. 135142). ACM.

[11] Wagner, D., Pintaric, T., Ledermann, F. and Schmalstieg, D., 2005, May. Towards massively multi-user augmented reality on handheld devices. In International Conference on Pervasive Computing (pp. 208-219). Springer, Berlin, Heidelberg.

[12] Paelke, V., Reimann, C. and Stichling, D., 2004, September. Foot-based mobile interaction with games. In Proceedings of the 2004 ACM SIGCHI International Conference on Advances in computer entertainment technology (pp. 321-324). ACM.

[13] Cheok, A.D., Sreekumar, A., Lei, C. and Thang, L.N., 2006. Capture the flag: mixed-reality social gaming with smart phones. IEEE Pervasive Computing, 5(2), pp.62-69.

[14] Crabtree, A., Benford, S., Rodden, T., Greenhalgh, C., Flintham, M., Anastasi, R., Drozd, A., Adams, M., Row-Farr, J., Tandavanitj, N. and Steed, A., 2004, April. Orchestrating a mixed reality game'on the ground'. In Proceedings of the SIGCHI conference on Human factors in computing systems(pp. 391-398). ACM.

[15] Hakkarainen, M. and Woodward, C., 2005, June. SymBall: camera driven table tennis for mobile phones. In ACM International Conference Proceeding Series (Vol. 265, pp. 391-392).

[16]Henrysson, A., Billinghurst, M. and Ollila, M., 2006, July. AR tennis. In ACM SIGGRAPH 2006 Sketches (p. 13). ACM.

[17] Szalavári, Z., Eckstein, E. and Gervautz, M., 1998, November. Collaborative gaming in augmented reality. In Proceedings of the ACM symposium on Virtual reality software and technology (pp. 195204). ACM.

[18] Björk, S., Falk, J., Hansson, R. and Ljungstrand, P., 2001. Pirates! Using the Physical World as a Game Board. In Interact (Vol. 1, pp. 423-430).

[19] Thomas, B., Close, B., Donoghue, J., Squires, J., De Bondi, P., Morris, M. and Piekarski, W., 2000, October. ARQuake: An outdoor/indoor augmented reality first person application. In Wearable computers, the fourth international symposium on(pp. 139-146). IEEE.

[20] Oda, O., Lister, L.J., White, S. and Feiner, S., 2008, January. Developing an augmented reality racing game. In Proceedings of the 2nd international conference on INtelligent TEchnologies for interactive enterTAINment (p. 2). ICST (Institute 
for Computer Sciences, Social-Informatics and Telecommunications Engineering).

[21] Andersen, T.L., Kristensen, S., Nielsen, B.W. and Grønbæk, K., 2004, June. Designing an augmented reality board game with children: the battleboard 3D experience. In Proceedings of the 2004 conference on Interaction design and children: building a community (pp. 137-138). ACM.

[22] Thakar, N., 2014. A design-led investigation of augmented reality: a case of AR for board games. $\mathrm{PhD}$ thesis. School of Architecture and Design. RMIT University. Australia.

\section{ДИЗАЈН ИГРЕ НА ТАБЛИ СА ПРОШИРЕНОМ СТВАРНОШЋУ}

\section{Т. Ризов, Ј. Ђокић, М. Ташевски}

Овај рад представља процес дизајна игре на табли са проширеном стварношћу. Друштвене игре су остале атрактивне у овом тренутку потпуне дигитализације. Спретност руку у игри била је главна карактеристика игре на табли. Увођењем AR у игре на табли ова кључна карактеристика чува се заједно са дигитализацијом неких елемената игре. Игре у проширеној стварности пружају играчима богат и потенцијално неограничен опсег могућности интеракције. Имплементација AR ствара додатну вредност игри. Желимо да побољшамо искуство игре комбинујући најбоље особине класичних игара на плочи са видео играма. За разлику од видо игара, предности играња друштвених игара су бројне. Увођењем AR, игра ће привући и играче видео игара.

Овај рад представља пример дизајна онога што је познато као AR Board Game, класа стоних игара која комбинује ручне уређаје (као што су паметни телефони) са физичком игром да би се креирао спој физичке и виртуелне игре на површини табли. Уз то, у раду се описује процес дизајнирања игре на плочи која укључује AR, заједно са техничком имплементацијом. Процес пројектовања се изводи помоћу познатих принципа (слика 1).

Циљ истраживања је да се идентификују предности које играчи имају од увођења дигиталне технологије у аналогни свет друштвених игара. Упоређује се искуство корисника у случају коришћења само игре на плочи и игре на плочи са AR. За узорак који се разматра узети су у обзир играчи на табли, али и играчи видео игара. Представљени су и дискутовани резултати спроведеног поређења. На крају се презентира читаво искуство дизајнирања таквог производа и идеје за даљи рад. 